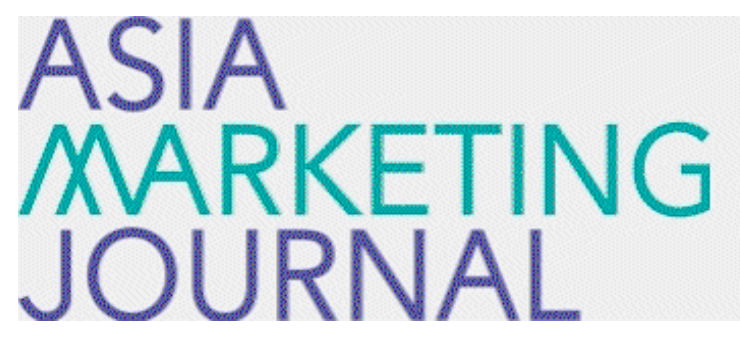

ASIA MARKETING JOURNAL

Volume 1 | Issue 4

Article 1

9-1-1999

\title{
세그먼트 변화를 추적하는 다차원척도법
}

주영 김

Follow this and additional works at: https://amj.kma.re.kr/journal

Part of the Marketing Commons

\section{Recommended Citation}

깁, 주영 (1999) "세그먼트 변화를 추적하는 다차원척도법," Asia Marketing Journal: Vol. 1 : Iss. 4 , Article 1. Available at: https://doi.org/10.53728/2765-6500.1022

This Article is brought to you for free and open access by Asia Marketing Journal. It has been accepted for inclusion in Asia Marketing Journal by an authorized editor of Asia Marketing Journal. 


\title{
세그먼트 변화를 추적하는 다차원척도법*
}

\author{
김 주영 (국민대학교 경상대학 경영학전공 조교수)
}

j ki n@km. kookmi n. ac. kr

\begin{abstract}
국문요약
포지셔닝맵은 마케팅전략의 핵심인 STP전략을 세우는데 유용한 도구이나 포지셔닝맵을 그리기 위해서는 여러 가지 분석도구를 혼합하여 사용하여야 하였다. 본 논문에서는 완벽하지 않은 소비자 pi ck any/N자료와 상표의 특성자료를 이용하여, 세분시장을 모델 내에서 구분하고, 이들의 이상점을 찾아주고, 나아가서 시간의 흐름에 따라 이상점의 변화를 찾아주면서 포지셔닝맵을 그려주는 새로운 external 다차원척도모형을 제시하고 있다. 모델의 성과를 확인하기 위해서 차원의 변화, 세분시장변화, 상표구성의 변화 및 소비자표본의 변화를 임의로 만들어서 가상의 자료를 통해서 검증하였다. 실제로 사용해 보려면 저자의 홈페이지에서 프로그램을 다운 받을 수도 있다.
\end{abstract}

키워드 : external 다차원척도법, 선택모형, 포지셔닝맵, STP전략, 동적모형, 세분시장 


\section{1. 서론}

마케팅전략의 기본은 시장세분화, 목표시장선정, 포지셔닝전략( segnent at i on, targeting, positi oni ng; STP strategy) 이라는 것은 대부분의 마케팅 교과서들에서 쉽게 찾을 수 있는 사실이다. 포지셔닝맵(posi ti oni ng map)은 이러한 STP전략을 세우는데 있어서 도움을 주는 중요한 분석도구의 하나로 인정 받고 있다. 포지셔닝맵은 특정시장을 대상으로 하여 실제 로 존재하고 있는 경쟁 제품들간의 관계나 소비자들이 원하는 이상적인 제품들까지의 관계 를 그림으로 표시해 놓은 것을 말하며, 이러한 포지셔닝맵을 작성하는 여러 가지 방법들에 는 요인분석이나 군집분석, 다차원척도법등이 있다. ( $G$ reen 1970).

일반적인 포지셔닝맵에는 3 가지 구성요소가 있다. 첫 번째 구성요소는 맵의 기본골격을 형 성하는 축이다. 보통 축의 수는 2-3개가 되어 맵은 2차원 혹은 3차원공간에 그려지게 된다. 각 축은 가격을 나타낼 때도 있고, 디자인을 나타낼 때도 있으며, 또 품질이나 중후함 등과 같이 소비자들이 제품을 선택하거나 특정시장을 이해할 때 사용하는 변수를 대표하기도 한 다.

두 번째 구성요소는 제품 혹은 상품들이다. 제품들은 포지셔닝맵을 구성하는 차원/축의 속 성을 각 제품들이 얼마나 가지고 있는가에 따라서 포지셔닝맵에서의 위치가 결정된다. 예 를 들어서 현대자동차가 만드는 그랜져자동차의 위치는 그랜져가 가지고 있는 가격의 정도 나 중후함의 정도에 따라서 결정된다.

세 번째 구성요소는 제품을 구매하거나 평가하는 소비자들이다. 소비자들의 위치는 포지셔 닝맵을 구성하는 차원들을 기준으로, 소비자들이 가장 좋아하는 속성의 정도(이상점)에 따 라서 결정된다. 예를 들어 소비자 홍길동의 위치는 홍길동이 좋아하는 자동차의 중후함 정 도나 가격의 정도에 따라서 결정되게 된다. 이렇게 소비자 개인들의 위치를 표시할 수도 있지만, 보다 효과적으로 사용할 수 있는 소비자들의 위치는 비슷한 소비자끼리 모아놓은 세분시장의 위치, 즉 세분시장 소비자들이 대표적으로 좋아하는 제품의 위치를 표시한 것이 다. 이러한 포지셔닝맵 이외에도, 다른 종류의 포지셔닝맵도 찾아볼 수 있다 (e.g., El rod 1988; Cooper 1988; Si nha and DeSar bo 1998, Tver sky and Satt ath 1979).

하지만, 이와 같은 특성을 가진 포지셔닝맵을 쉽게 그려주는 분석도구는 쉽게 찾기 힘들며, 일반적으로 하나 이상의 분석도구를 이용하여야만 이러한 맵을 그릴 수 있다. 예를 들어, 요인분석은 포지셔닝맵을 구성하는 차원을 찾아주는 데에는 매우 효과적이고, 다차원척도법 ( mul ti di mensi onal scal i ng nødel)은 제품들의 상대적인 위치를 찾아주는데 효과적이다. 조 금 더 발달된 다차원척도법은 제품의 상대적인 위치뿐만 아니라 소비자들의 이상점이나 선 호경향을 찾아주기도 한다 ( Green and Wnd 1973; DeSarbo and Rao 1984; DeSarbo and Cho 1989). 또한 군집분석은 비슷한 소비자들을 묶어서 세분집단을 찾아주는데 아주 효과적인 방법이 다.

위에서 언급한 3가지의 구성요소를 모두 가진 포지셔닝맵을 그리기 위해서는 요인분석을 통 해서 차원을 구성하고, 각 차원별로 제품의 상대적인 위치를 구한다음, 소비자 개인의 이상 점을 찾아주는 다차원척도법을 사용해서 개별 소비자들의 이상점들을 찾은 후에, 이들을 이 
용해서 군집분석을 하여야 한다. 다른 방법으로는 군집분석을 이용해서 소비자를 먼저 세 분집단으로 묶은 후에, 이상점과 제품위치를 한꺼번에 찾아주는 방법을 (논문으로 발표된 모델은 많으나 상업용으로 쉽게 사용할 수 있는 분석도구는 찾기 힘들다; cf. PREFMAP) 이용 해서 차원, 세분집단, 제품의 위치를 동시에 찾는 방법도 있다.

이와 같이 실무적으로 효과적인 포지셔닝맵을 그리기 위해서는 서로 다른 분석도구를 하나 이상 조합하여 사용해야 한다. 하지만 포지셔닝맵을 그리기 위해서 사용하는 분석도구도 여러 가지이고, 이 분석 도구들을 조합하는 방법도 다양하기 때문에, 어떻게 포지셔닝맵을 그리는 것이 효과적인지 판단하기가 힘들다. 또한 방법론 상에서도 각 분석도구를 사용하 는 데에서 발생하는 오차의 방향이나 정도를 전체적인 관점에서 통제할 수가 없어서 포지셔 닝맵을 그리는 데에 있어서 오차의 크기가 커질 수 있는 가능성이 있다.

또 다른 문제는 포지셔닝맵의 비교에 관한 문제이다. 포지셔닝맵의 중요한 활용도의 하나 는 제품들의 특성이 변화함에 따라서, 또 시간이 지남에 따라서 세분시장의 위치변화 즉, 소 비자들의 선호도가 어떻게 변화하는 지를 파악하여 미래에 활용할 전략을 짜는 것이다. 하 지만 기존의 다차원척도법은 시간이 지남에 따라서 세분시장의 변화를 파악하는데 도움을 주지 못하고 있다. 기존의 다차원척도법은 각 시점별로 별도의 포지셔닝맵을 만든다. 따 라서 서로 다른 시점의 포지셔닝맵을 비교하기 위해서는 비교하는 시점의 포지셔닝맵의 공 간 혹은 차원이 동일하여야 하는데, 포지셔닝맵의 공간이 시점별로 같다고 하기가 힘들기 때문이다.

포지셔닝맵의 공간이 동일하다는 특성은 도형의 불변성 (configural invari ance) 이라고 해 서 제품의 위치만 변하고 공간자체는 변하지 않는 다는 것을 의미한다 (Mbi npour et al. 1976; Green et al. 1969). 따라서 도형의 불변성이 없는 작년에 그린 포지셔닝맵과 올해의 포지셔닝맵은 비슷하게 보여도, 실제 차원의 의미는 같다고 볼 수 없었다. 이러한 문제점 은 동일한 시점에 다른 지역의 소비자를 대상으로 그린 포지셔닝맵에서도 찾아볼 수 있다. 기존의 유사성 다차원척도법에서는 서로 다른 맵을 비교하는 데에는 요인의 축을 회전시키 는 fact or matchi ng방법들이 사용되었다 (Peay 1988). 그 중에서 많이 사용되는 방법은 C match방법이며 ( Cliff 1969), 김근배와 이훈영(1995)은 몇 개의 제품좌표를 고정시키는 방 법을 제안하고 이를 다른 방법들과 비교하였다. 유사성 다차원척도법에서는 제품들간의 상 대적인 위치만이 표시되기 때문에 이와 같은 방법도 사용할 수 있었지만, 선호/선택 다차원 척도법에서는 소비자의 위치도 같이 표시되기 때문에 제품을 고정시키는 방법만으로는 도형 의 불변성을 유지할 수가 없다.

본 연구는 제품의 객관적인 정보가 주어진 상태에서 개별 소비자들의 선택자료, pick any/N 자료 (소비자들이 제품들을 몇 개씩 구매했는가) 을 이용하여 소비자세분집단을 구분하고, 제품의 위치와 세분집단의 위치를 한꺼번에 보여주는 포지셔닝맵을 그려주며, 과거시점과 현재시점의 소비자세분집단의 위치변동을 보여주는 external 다차원척도모델 방식인 새로운 다차원척도법을 제시하고자 한다. 


\section{2. 세그먼트 변화맵 구축의 문제점}

본 모델의 중요한 목적들은 첫번째로 손쉽게 전략적으로 유용한 포지셔닝맵을 그리는 것이 고, 두 번째로 세분시장의 움직임을 파악할 수 있도록 하는 것이며, 세 번째로 통계적으로 안정된 결과를 보여주는 것이다. 기존의 방법론들에서 문제로 지적되었던 요소들과, 실무 적으로는 필요성이 인식되었으나 기존 모델들에서는 해결해 주지 못했던 점들을 살펴보기로 하겠다.

\section{1 포지셔닝맵 차원의 의미}

제품의 위치와 소비자의 이상점을 동시에 그려주는 internal 다차원척도법을 통한 포지셔닝 맵의 차원들을 이해하기 위해서는 제품의 특성들에 대한 자료를 별도로 이용하여 포지셔닝 맵상에 vector형태로 표시하거나, 혹은 제품특성자료를 이용하여 포지셔닝맵상의 상표들의 위치를 재모수화(reparameterization)하기도 하고, 가장 간단하게는 포지셔닝맵상의 상표들 의 위치를 보고 각 축의 양극단에 위치한 상표의 특성을 주로 고려하여 주관적인 차원의 해 석을 하는 방법이 있다. (Davi son 1983; Green 1972; Carroll and Arabi e 1980)

하지만 제품위치나 소비자 이상점 중 한가지만을 그려주는 external 다차원척도법의 경우에 는 포지셔닝맵상의 특정 상표들 혹은 사용자들의 이상점이 정해져 있기 때문에 맵의 차원이 결정되어서 모델의 결과로 나온 포지셔닝맵을 별도로 해석하는 것이 필요하지 않다 (Green and Wnd 1973). 또한 맵의 차원 및 의미가 결정되어있기 때문에 모수의 추정도 상당히 안 정적이 된다. 하지만 external 모델의 경우 입력되는 자료들, 상표들의 위치등에 따라서 포 지셔닝맵의 해석이 전적으로 결정되기 때문에, 입력자료의 성격이 상당히 중요해 진다.

사용될 수 있는 입력자료로는 제품특성 변수들을 요인분석한 상표들의 요인점수나 혹은 유 사성 다차원척도모델을 적용하여 얻은 상표들의 위치 등이 사용되어져 왔다 ( Green and Wnd 1973; Davi si on 1983; Cooper s and Nakani shi 1983). 이외에도 사용되어질 수 있는 입력자 료는 제품의 대표적인 특성이 있다. external 모델에서 입력자료로 활용되는 상표의 위치 나 제품의 특성의 차원이 곧 external 모델자체의 차원이 되므로 모델의 성과에 직접적인 영 향을 미친다. 제품의 특성은 일반적으로 선택모형등에서 소비자들의 선택행동을 설명하는 데 많이 사용이 되며, 포지셔닝맵에서 사용이 된다면 포지셔닝맵의 차원이 상표들의 특징이 되어 이해하기가 쉽다고 할 수 있다.

\section{2 포지셔닝맵 차원의 결정}

기존의 다차원척도법에서는 최적의 포지셔닝맵의 차원을 결정하는 것은 포지셔닝맵의 이름 을 결정하거나 이해하는 것과 마찬가지로 가장 힘든 것 중의 하나라고 할 수 있다 (Young 1987, Carroll and Arabi e 1980). 기존의 다차원척도법 모델들에서는 모델자체의 설명력을 알 려주는 badness- of fit 값 혹은 stress값을 이용해서 차원의 증가에 따라서 값의 변화가 눈 1999. 9 
에 띄게 줄어드는지를 보는 el bow방법에 의해서 차원의 수를 결정하였다. 이러한 방법은 탐색적인 요인분석에서 요인 수를 결정하는 것과 비슷하다고 할 수 있다. 확률적인 다차원 척도모델들에서는 일반적으로 likeli hood 함수의 특성으로 나타나는 적합도 지수나 혹은 모 델 모수의 통계적유의도 등에 의해서 차원수를 결정한다. (Jedi di and DeSarbo 1991; Ran\$ay 1977; DeSar bo and Rao 1984)

기존의 internal 다차원척도법에서는 주로 통계적인 의미를 강조하여 차원의 수를 결정하였 지만, external 모델의 경우에는 통계적인 의미에 따른 단순한 차원의 수보다는 각 차원의 의미도 고려하여야 할 것이다. 또한 기존의 internal 다차원척도법에서는 차원의 순서에 따라서 통계적 중요도나 차원의 설명력이 큰 모델도 있었으나, external 모델의 경우에는 이 러한 특성은 없으며, 각 차원별로 통계적으로 유의하고, 의미적으로 해석이 적절한 차원을 순서에 관계없이 선택하여야 할 것이다.

\section{3 공간축소(degener acy) 의 문제}

기존의 internal 다차원척도법의 가장 큰 문제점의 하나는 유사성다차원척도법이나 선호/선 택 다차원척도법에서 모두 볼 수 있는 공간축소의 문제점이다. 공간축소는 실제상황이나 자료에 상관없이 제품들 혹은 제품과 소비자들의 이상점의 위치가 일정한 양태를 보이는 것 을 의미한다 (DeSarbo et al. 1997; DeSarbo and Rao 1984). 이러한 것을 근원적으로 없애 주는 방법은 아직 개발 중이기는 하지만, 주로 stress 공식을 다양하게 적용하거나, 자료를 이용하는 비중을 다르게 하거나, 비모수기법을 사용하는 것이 사용되어지고 있다.

이러한 공간축소의 문제점을 해결하는 또 다른 방법은 external 다차원척도법을 활용하는 것이라고 할 수 있다. external 방법은 공간축소문제 뿐만 아니라 internal 방법이 가지고 있는 내재적인 회전, 이동 등의 부적정화( i ndetermnacy problem) 를 없애준다.

\section{4 포지셔닝맵의 변화}

시간의 차이가 있는 경우를 고려한 포지셔닝맵의 변화의 원인은 3 가지로 나누어 볼 수 있다. 첫째는 실제의 제품이나 소비자 이상점의 위치 변동이고, 둘째는 모델에서 위치를 추정할 때 발생하는 오차, 셋째는 포지셔닝맵의 차원 혹은 공간의 변동이다. 이 세가지의 요인을 분리할 수 있어야만, 마케팅의사결정자가 원하는 제품이나 소비자들의 실제의 위치변동을 알려줄 수 있게 된다. 세가지 요인을 분리하는 데 있어서 가장 큰 문제는 제품이나 소비자 이상점의 위치변동과 포지셔닝맵 차원의 변화가 구분되지 못한다는 것이다.

기존의 다차원척도법을 단일시점에서 활용하는 경우에는 시간의 흐름에 따른 포지셔닝맵의 변화는 문제로 인식되지 않았었다. 단지 기존의 다차원척도모델에서는 서로 다른 표본을 대상으로 추출하는 포지셔닝맵들이 동일한 차원인지를 비교하고자 하였다. 유사성척도 모 델인 경우에 사용했던 방법은 요인의 축을 회전시키는 factor matchi ng방법과 좌표고정법들 이 사용되었다 (Peay 1988; Cliff 1969; 김근배와 이훈영 1995). 하지만 선호/선택 다차원 
척도법의 경우에는 포지셔닝맵의 비교가 시도된 적은 없었다.

또한 유사성자료를 이용한 다차원척도법의 포지셔닝맵 차원과 선호/선택 자료를 이용한 다 차원척도법의 포지셔닝맵의 차원은 두 개의 공간이 같다고 하는 주장도 있으며, 두 개의 공 간이 다르다는 주장도 있다. 두 개의 공간이 같다는 가정하에서는 유사성 다차원척도법에 서 나온 제품들의 위치를 그대로 선호/선택 다차원척도법에서 사용을 하거나, 유사성자료와 선호자료를 동시에 사용하여 포지셔닝맵을 추정하고 있다 (Green and Wnd 1973; Ramsay 1980) .

시간의 변화에 따른 분석을 할 때에는 필연적으로 포지셔닝맵 차원의 변화를 고려하여야 한 다. 포지셔닝맵 차원의 변화는 새로운 차원이 생기는 경우도 있고, 기존차원이 없어지는 경우도 있으며, 차원의 의미가 바뀌는 경우도 있을 수 있다.

새로운 차원이 생기는 경우는 소비자들이 제품을 선택할 때 고려하는 요소가 새로 추가되는 것을 의미하며, 많은 경우에 새로운 상표가 새로운 기능을 가지고 시장에 진입하였을 때 발 생한다. 예를 들어 새로운 입 냄새 제거상품이 미백효과를 가지고 시장에 진입하면, 소비 자들은 미백효과라는 차원을 제품구매할 때 경쟁 상표들의 입 냄새제거 기능뿐만 아니라 미 백효과가 있는 지를 평가하게 된다. 이러한 경우에 기존의 상표들은 미백효과차원에 0이란 값을 주고, 새로운 상표에는 1의 값을 주어서 새로운 차원입력자료를 만들어서 차원이 새로 생기는 효과를 모델에 반영할 수 있어야 할 것이다. 만약 모델전체의 적합도가 좋아지고, 차원가중치가 유의하면 소비자들이 선택행동을 할 때 새로운 차원을 고려한다고 할 수 있 다.

기존 차원이 없어지는 경우는 소비자들이 더 이상 선택할 때 제품의 특정 특성을 별로 고려 하지 않는 경우에 해당된다. 즉, 상표나 세분시장의 위치가 차이가 나지 않고, 해당차원을 빼고 모델을 적용한 결과의 Iikelihood함수관련 관련 통계치 들이 큰 차이가 없애면, 통계 적으로 차원을 없앨 수도 있어야 한다.

차원의 의미가 바뀐다는 것은 기존의 차원을 형성하였던 특정 제품특성이 없어지고 비슷한 새로운 제품특성으로 차원을 형성한다는 것을 의미하며, 차원을 없애는 것과 새로운 차원을 형성하는 것은 위에서 언급한 것과 같다.

이와 같이 포지셔닝맵의 변화를 제품 및 이상점의 변화와 별도로 모델에서 구분해주어야 시 간변화에 따른 제품, 이상점의 변화를 제대로 파악할 수 있게 된다.

\section{5 상표의 도입/제거 및 특성변화}

상표의 위치가 시간에 따라 변화하는 것을 그려주는 포지셔닝맵에서는 당연히 시간에 따른 상표의 수의 변화 및 상표들의 특성변화를 포함하여야 한다. 기존의 다차원척도법에서도 상표의 도입/제거나 변화된 특성은 그대로 모델에 적용시킬 수 있었지만, 상표도입전과 후 나 특성변화전과 후는 비교할 수 없었다. 비교가 가능하기 위해서는 시간이 흐름에 따라서 포지셔닝맵의 차원의 변화가 명확하게 상품들의 위치변화와 구분되어야 하는데 기존의 다차 원척도법은 이러한 것이 명확히 구분되지 못했기 때문이다.

1999. 9

세그멘트변화를 추적하는 다차원척도법 6 
한 국 마 케 팅 저 널 제 1 권 제 4 호

하지만 포지셔닝맵의 차원변화가 구분된다 하더라도 상품의 위치와 이상점의 위치가 동시에 찾아진다면, 상품위치와 이상점 위치의 변동을 구분하는 것은 안정적이기 힘들다. 따라서 상품을 고정하거나 혹은 소비자의 이상점을 고정하여 포지셔닝맵을 고정하고 고정하지 않은 소비자 이상점이나 상품의 위치변화를 보는 것이 안정적이다.

신제품등과 같이 소비자들이 잘 모르는 상품이 시장에 출시된 경우에 기존의 선호/선택 다 차원척도법의 경우에 이들에 대한 자료가 가지고 있는 정보가 기존의 상품에 대한 정보보다 신뢰성이 떨어진다고 해서 포지셔닝맵을 구축할 때 이들에 대한 정보에 적은 가중치를 주어 서 더 좋은 포지셔닝맵을 구축하려는 노력들이 있었다 (DeSarbo and Rao 1984). 선택자료를 이용한 경우에는 선택되지 못한 상품의 정보는 자동적으로 포지셔닝맵 관련 모수를 추정할 때 상대적으로 적게 사용하게 되어 유사성다차원척도나 선호모형에서 보여질 수 있는 편기 는 적다고 할 수 있다. 따라서 선택모델의 결과로 나타나는 예상 선택과 실제 선택간의 차 이는 품질이나 선호는 좋은데, 실제 인지도가 부족하거나 다른 마케팅전략변수에서 떨어진 다는 것을 나타내 주는 정보라고 할 수 있다.

\section{6 세분시장의 수의 결정과 변화}

세분시장을 구분하는 방법은 상당히 다양하지만 모델적용 전에 미리 결정하지 않고 모델 내 에서 세분시장의 특성과 수를 결정하는 방법 중에는 I atent cl ass방법이 많이 사용된다. 대부분의 I atent class 모델을 적용하는데 힘든 부분은 I atent cl ass의 최적숫자를 결정하는 것이다. 최적숫자를 결정하는데 필요한 정보들로는 모델 전체의 적합도 추정치 들( $\mathrm{AlC}$, CAI C, BI C) 이다 (Grover and Sri ni vasan 1987; Wedel and DeSarbo 1996). 또한 이러한 통계 적인 수치들 외에도 모수추정치들의 값들이 의미 있는지를 같이 판단하고 있다.

특히 동적인 모델인 경우에는 현재 세분시장의 수가 과거와 변하는 경우를 고려해야 한다. 일반적으로 시장이 성장기나 성숙기에 들어가게 되면, 소비자들이 제품들에 대하여 지식이 늘어나게 되고 이에 따라서 초기에는 세분화되지 않았던 소비자시장이 점차 독특한 특성을 지닌 세분시장으로 구분된다. 또한 쇠퇴기에 들어서면, 세분되었던 시장들이 다시 뭉쳐지 거나 혹은 과거의 세분시장이 없어지는 경우도 찾아볼 수 있다. 혹은 세분시장의 전체 수 는 바뀌지 않았지만, 그 특성이 바뀌는 경우도 있을 수 있다.

과거의 정태적인 다차원척도모델에서는 고려하지 않아도 되는 이러한 현상들이 동적모델에 서는 중요한 문제로 부각된다. 이렇게 세분시장의 수와 그 특성이 바뀜에 따라서, 소비자들 이 동적으로 어떤 세분시장에 속하게 되는가도 역시 마케팅관리자에게는 관심 있는 정보가 될 수 있다.

\section{7 표본이 완벽하게 동일하지 못한 동적인 자료}

마케팅의 많은 모델들이 동적이지 못한 이유중의 하나는 자료를 구하기 어렵다는데 있다. 1999. 9 
한 국 마 케 팅 저 널 제 1 권 제 4 호

최근에는 패널들이 생겨서 가능해졌지만, 실제로 동일한 사람들의 자료를 계속 얻기는 용이 하지 않다. 따라서 동적모델 들이 실제로 잘 활용되기 위해서는 개인수준에서는 동일한 소 비자가 아니더라도 비슷한 구매행동을 보이는 소비자들의 자료들을 이용해서 동적인 구매행 동의 변화를 찾아낼 수 있는 모델이 필요하다고 할 수 있다.

이를 위해서는 전체 표본에서 빠지거나 바뀐 개인들의 자료를 추정해주는 모델이 필요하다. 이러한 경우에 적용될 수 있는 다른 모델은 개인수준이 아닌 세분시장 수준의 모델을 개발 하는 것이다. 세분시장 수준의 모델에서는 각 개인의 정보가 완벽하지 않아도 집단수준의 모수를 찾을 수 있다. 또한 각 개인의 자료가 시간적으로 확인될 수 있으면, 각 개인이 시 간이 변함에 따라, 또 세분시장의 특성이 변함에 따라 세분시장 귀속이 변하는 것을 살펴볼 수도 있을 것이다.

\section{3. 모델의 구축}

\section{1 모델의 가정}

본 모델을 구축하기 위해서는 본 모델에서 가정하고 있는 소비자들의 선택행동과 모델구축 에 필요한 요소들을 명확하게 할 필요가 있다. 이러한 요소들은 다음과 같다.

1) 소비자들의 제품 선택행동은 구매가능한 상표들을 구매한 개수들로 대표되며, 이러한 제품 선택행동은 각각의 상표들을 구매할 확률로 이루어진 다항확률분포(mul ti nomal di stri buti on) 를 이룬다 (Ramaswany and DeSarbo 1990; 김주영 1999) .

2) 각각의 상표들을 구매할 확률은 소비자들이 속한 세분시장의 이상점의 위치와 각 상표들 의 위치 간의 거리를 이용한 로짓함수에 의하여 계산되어 진다 (Cooper and Nakani shi 1983). 거리의 역수가 효용을 나타낸다는 가정하에서 효용을 구매확률로 전환해주는 대표적인 로짓 함수를 사용한 것이다. 결과적으로 이상점과 거리가 멀수록 각각의 상표들을 구매할 확률 은 작아진다.

3) 전체 세분집단의 숫자와 특성이 사전에 정해지지 않으며, 각각의 소비자들도 어떤 세분집 단에 포함될지 정해지지 않는다. 세분화는 I atent class방법에 의해서 이루어지며, 개별 소 비자들은 하나의 세분시장에 배당되는 것이 아니라 모든 세분시장에 속할 확률 값을 가지게 된다 ( Grover and Sri ni vasan 1987; Wedel and DeSarbo 1996).

4) 상표의 위치와 포지셔닝맵의 차원 혹은 공간은 모델의 입력자료로 주어지게 된다. 상표 의 위치는 소비자의 선택행동에 영향을 미치는 제품의 특성이나 혹은 요인분석과 같은 다른 분석도구의 결과값을 이용할 수 있다.

5) 세분시장 위치의 변화는 과거의 세분시장위치에 기초하여, 이번기의 소비자 선택행동에 따라 추정되어 진다. 만약 과거 세분시장의 위치가 없으면, 현재의 세분시장위치가 추정된 다. 과거 세분시장의 위치가 있는 경우에 현재 세분시장의 위치는 과거 세분시장위치와 추 1999.9 
정된 세분시장 위치변화를 더하면 얻을 수 있다.

\section{2 모델의 구축}

이상의 모델 구성 요소 및 가정을 이용하여 모델을 구축하도록 하겠다. 먼저, 본 논문에서 사용하는 변수들은 다음과 같이 정의된다.

I : 소비자

$\mathrm{J}$ : 상표 혹은 제품

$S$ : 소비자 세분시장

$\mathrm{K}$ : 포지셔닝맵의 차원

$\mathrm{d}_{\mathrm{sj}}$ : 시간 $\mathrm{t}$ 에서 세분시장 $\mathrm{s}$ 의 이상점에서 상표 $\mathrm{j}$ 까지의 거리

$a_{k t}$ : 포지셔닝맵의 차원 $\mathrm{k}$ 상에서 세분시장 $\mathrm{s}$ 의 이상점이 시간 $\mathrm{t}$ 에 이동한 거리

$\mathrm{Y}_{\mathrm{sk}}$ : 전기에 포지셔닝맵의 차원 $\mathrm{k}$ 에서 세분시장 $\mathrm{s}$ 의 이상점이 위치

$\mathrm{X}_{\mathrm{jkt}}$ : 시간 $\mathrm{t}$ 에 포지셔닝맵의 차원 $\mathrm{k}$ 상에서 상표 $\mathrm{j}$ 의 위치

$\mathrm{e}_{\mathrm{sj} t}$ : 시간 $\mathrm{t}$ 에서 세분시장 $\mathrm{s}$ 의 이상점에서 상표 $\mathrm{j}$ 까지의 거리의 오차항

$\mathrm{C}_{\mathrm{ijt}}$ : 소비자 $\mathrm{i}$ 가 시간 $\mathrm{t}$ 에 상표 $\mathrm{j}$ 를 선택한 개수 ( pick any/M)

$\mathrm{S}_{\mathrm{st}}$ : 시간 $\mathrm{t}$ 에 소비자 $\mathrm{i}$ 가 세분시장 $\mathrm{s}$ 에 속할 확률

만약 소비자 $\mathrm{i}$ 가 시간 $\mathrm{t}$ 에 세분시장 $\mathrm{s}$ 에 있다고 할 때, 시간 $\mathrm{t}$ 의 소비자가 속한 세분시장 $\mathrm{s}$ 에서 상표 j 까지의 거리는 다음과 같이 Eucl idean di stance의 제곱으로 구하여 진다.

$$
d_{s j}^{t}=\sum_{k}\left(Y_{s k}^{t}+\alpha_{s k}^{t}-X_{j k}^{t}\right)^{2}+e_{s j}
$$

거리는 과거의 세분시장 이상점의 위치, $\mathrm{Y}_{\mathrm{sk}}$ 에 현재시점에서 세분시장 이상점의 이동, $\mathrm{a}_{\mathrm{kt}}$ 를 더하여 나온 현재시점의 세분시장 이상점의 위치에서 상표의 위치, $X_{j k t}$ 까지의 거리로 계 산되어 진다.

위 [ 식1] 의 거리를 이용해서 시간 t에 소비자 i 가 세분시장 s에 속한다고 할 때, 소비자 i 가 상표 $\mathrm{j}$ 를 선택할 확률은 거리계산의 오차항이 extrene val ue 분포를 따른다고 하면, 다음 과 같이 로짓함수로 구할 수 있다.

$$
P_{i j \mid s}^{t}=\frac{e^{-d_{s j}^{t}}}{\sum_{j} e^{-d_{s j}^{t}}}
$$


만약, 소비자의 시장에서 구매할 수 있는 여러 가지 제품을 구매하는 행동이 각 제품을 구 매하는 확률에 기초한 다항분포 (mul ti nomal di stribution) 를 따른다고 가정하면, 소비자 $\mathrm{i}$ 가 세분시장 s에 속할 때의 경쟁제품 들을 구매하는 conditional 확률은 다음과 같다.

$$
\begin{aligned}
P_{i \mid s}^{t} & =\frac{\left(\sum_{j} C_{i j t}\right) !}{\prod_{j} C_{i j t} !} \prod_{j}\left(\frac{e^{-d_{s j}^{t}}}{\sum_{j} e^{-d_{s j}^{t}}}\right)^{C_{i j t}} \\
& =\frac{\left(\sum_{j} C_{i j t}\right) !}{\prod_{j} C_{i j t} !} \prod_{j \neq J}\left(\frac{e^{-d_{s j}^{t}}}{1+\sum_{j \neq J} e^{-d_{s j}^{t}}}\right)^{C_{i j t}}\left(\frac{1}{1+\sum_{j \neq J} e^{-d_{s j}^{t}}}\right)^{C_{i J t}}
\end{aligned}
$$

3)

위 [ 식3]에 각 소비자 i 가 세분시장 s에 속할 확률 값을 곱하고 이를 모든 세분시장별로 더 하면, unconditional 확률을 아래와 같이 구할 수 있다.

$$
P_{i}^{t}=\sum_{s} S_{i s}^{t} \times P_{i \mid s}^{t}
$$

마지막으로, 각 소비자들의 구매행동이 서로 독립이라고 가정하면, 전체 likeli hood 함수는 아래와 같다.

$$
\begin{aligned}
L & =\prod_{i} P_{i}^{t} \\
& =\prod_{i}\left(\sum_{s} S_{i s}^{t} \times P_{i \mid s}^{t}\right) \\
& =\prod_{i}\left[\sum_{s} S_{i s}^{t} \times \frac{\left(\sum_{j} C_{i j t}\right) !}{\prod_{j} C_{i j t} !} \prod_{j}\left(\frac{e^{-d_{s j}^{t}}}{\sum_{j} e^{-d_{s j}^{t}}}\right)^{C_{i j t}}\right]
\end{aligned}
$$

\section{3 모델 모수의 추정}

모델의 모수를 추정하기 위해서, I at ent cl ass분석방법에서 많이 사용하는 E-M 방법을 사용 하였다. E-M방법은 기본적으로 Iikeli hood 함수의 모수를 추정하는데 있어서 초기값을 
$\mathrm{E}$ (expectat i on) 단계와 M maxi mizati on) 단계를 번갈아가면서 계속 적용하면서 최적 모수추정 치를 찾아가는 방법이다. E단계에서는 소비자들이 각 세분시장에 속하는 확률값, $\mathrm{S}_{\mathrm{st}}$ 을 전 단계인 $\mathrm{M}$ 탄계에서 추정한 다른 모수들의 값에 기초해서 베이지안방법에 따라 구해낸다. $\mathrm{M}$ 단계에서는 역시 $\mathrm{E}$ 단계에서 구한 모수값, $\mathrm{S}_{\mathrm{st}}$ 을 주어진 것으로 가정하고 다른 모수들, $\mathrm{a}_{\mathrm{kt}}$ 을 numerical search방법 (구체적으로 Quasi-Nent on방법)을 이용하여 [ 식5]에 나온 likel i hood 함수에 log를 취한 Iog-likelihood함수를 극대화 시키는 값으로 추정해 낸다. 아래 [식6]은 E단계에서 새로운 $\mathrm{S}_{\mathrm{st}}$ 값을 구하는 공식을 나타내고 있고, [ 식7]은 l og- I i kel i hood함수를 보여주고 있다.

$$
\begin{gathered}
S_{i s}^{t}=\frac{S_{i s}^{t} \times P_{i \mid s}^{t}}{\sum_{s} S_{i s}^{t} \times P_{i \mid s}^{t}} \\
\log L_{t}=\sum_{i} \log \left(P_{i}^{t}\right)
\end{gathered}
$$

요약하여 보면, 시간 $\mathrm{t}$ 에 모델에 들어가는 입력자료는 소비자들이 경쟁상표 들의 구매한 숫 자들 $\mathrm{G}_{\mathrm{jt}}$ (pick any/N선택자료; 자료의 수는 [IxJ]) 와 상표의 특성으로 이루어진 상표위치, $\mathrm{X}_{\mathrm{jkt}}$ (자료의 수는 [JXK]) 가 있다. M탄계에서 추정하여야 하는 모수의 수는 세분시장 이상 점의 변화모수, $a_{k t}$ (모수의 수는 $[\mathrm{KxS}]$ ) 가 된다.

\section{4 모델 opt i on들}

위의 기본 구조를 유지하면서, 실제 자료를 수집하면서 발생할 수 있는 여러 가지 경우 및 결과의 Iocal 최적치 문제를 완화하기 위해서 여러 가지 모델 초기값 opti on을 개발하였다. 비선형구조를 가지고 있는 대부분의 모델들과 같이, 본 모델도 모수의 초기치에 따라서 모 수추정치가 항상 동일하게 나오지 않는다. 따라서 $\mathrm{M}$ 방식으로 추정한 모수추정치가 항상 최적인지에 대한 확신을 하기 힘들다. 따라서 많은 기존 모델들에서처럼 만족할 만한 모수 추정치를 갖기 위해서는 처음부터 의미 있는 모수 초기치를 사용하는 것이 필요하며, 또 몇 개의 모수 초기치를 이용한 결과를 비교하여 최적의 결과를 선택하는 것이 바람직하다.

\subsection{1 응답자들의 세분시장 귀속 확률 초기값}

본 모델에서는 응답자들이 각각의 세분시장에 속할 확률의 초기값을 생성하는 세가지 옵션 이 있다. 물론 이러한 초기값을 지정해 주기 위해서는 먼저 세분시장의 개수를 정하여야 한다.

(1) 첫 번째 옵션은 무작위수(randomnunmer) 를 생성하여 개인별로 각 세분시장에 속할 확률 1999. 9 
값의 합이 1 이 되도록 조정하여 초기치로 사용하는 방법이다.

(2) 두 번째 옵션은 먼저 응답자들의 각 상품에 대한 pick any/N선택자료를 이용하여 K- Means군집분석을 통하여 응답자들을 구분한다. 같은 군집에 속한 응답자들의 선택자 료를 모두 더하여서 군집수준의 평균 선택자료를 만든다. 이 평균선택자료와 각 개인 의 선택자료와의 차이를 구하고 이를 이용하여 각 군집에 속할 확률 초기값을 구한다. 이때, 만약 본 모델을 돌린 과거결과, 즉 지난기의 세분시장위치 추정치가 있으면, 군집 분석을 통하여 나온 세분시장의 특성과 가장 비슷한 과거 세분시장을 찾아 응답자가 속 한 군집을 조정한다.

(3) 세 번째 옵션은 만약 과거에 본 모델을 이용하여 분석한 결과가 있고, 그때 사용된 응답 자와 이번자료의 응답자가 동일한 경우에는 과거 세분시장 귀속확률을 그대로 사용하는 것이다.

(4) 네 번째 옵션은 연구자가 별도로 초기치 값을 직접 결정하는 방법이다.

\subsection{2 세분시장 이동에 대한 초기값}

세분시장이동의 초기값은 앞의 세분시장 귀속확률에 연동되어 결정하는 것이 바람직하며, 역시 세가지의 옵션이 있다. 이를 위해서는 역시 세분시장 개수에 대한 결정을 하여야 하 며, 이 개수는 세분시장 귀속확률에 사용한 개수와 같아야 한다.

(1) 첫 번째 옵션은 무작위수(random number)를 생성하여 초기치로 사용하는 방법이다.

(2) 두 번째 옵션은 세분시장별로 각 개인의 세분시장 귀속확률을 가중치로 사용하여 각 개 인이 선택한 상품들의 위치들을 더하여서 세분시장의 현위치 예상치를 구한다. 만약 과거 분석자료가 있으면, 세분시장 현위치 예상치에서 과거 세분시장 위치를 빼서 세분 시장 이동 초기값을 구한다.

(3) 세 번째 옵션은 과거 세분시장위치에서 이동하지 않았다는 가정하에서 세분시장이동 초 기값을 0 으로 정한다.

(4) 네 번째 옵션은 연구자가 별도로 초기치 값을 직접 결정하는 방법이다.

\section{4. 모델의 검증}

\section{1 모델 검증 방법}

본 모델이 실제적으로 제대로 소비자들의 집단을 구분해내고, 그 집단의 위치를 찾아내며, 시간에 따른 변화를 추적해 내는 지를 검증하였다. 검증방법은 가상의 자료를 만들어서 모 델이 원래의 값을 제대로 복원하는 지를 검토하는 방법을 취하였다. 먼저 상품의 위치를 가상적으로 정하고, 소비자들의 이상점위치도 가상적으로 정한다음에, 이를 바탕으로 가상의 
선택자료를 만들어 내었다. 다음으로는 모델에는 선택자료와 상품의 위치만을 입력하여, 소비자집단 구분 및 집단 이상점의 위치가 제대로 추정되고, 모델의 예측력 및 차원수 등을 잘 찾아주는 지를 검증하였다.

실제자료를 이용해서 검증하지 않는 이유는 실제자료에는 소비자의 집단이 구분되어 있지 않으며, 각 집단이 선호하는 위치도 알려져 있기 때문에 실제자료를 이용해서 나온 모델의 결과를 평가할 수 없기 때문이다. 또한 현재의 모델과 비슷한 결과를 내는 단일 모델을 정 하기가 힘들어서, 다른 모델과 비교를 하지 못하였다. 차후에 패널자료를 얻기 쉽고, 이를 통한 실제 활용이 많아지면, 여러 가지 산업이나 상황에 적용해본 결과들을 모아서 모델유 용성에 대한 검토를 하고자 한다.

검증과정은 크게 1) 현재상태를 제대로 추정하는 지, 2) 세분시장의 수가 변동되는 것을 알 아내는지, 3) 차원의 수가 변하는 것을 반영하는지, 4) 응답자가 변동되었을 때 안정적인지 등의 검증으로 나누어 진다.

\section{2 모델 검증 결과}

\subsection{1 현재상태 추정 $(t=1)$}

모델검증을 위해서 먼저 처음 본 모델을 적용하는 경우를 검증하고자 한다. 소비자들은 상 표들을 선택할 때 2 개의 특성 혹은 차원으로 상표들을 평가한다고 가정하고 가상의 선택자 료를 만들었다. 이를 위해서 상표들(15개)의 위치는 [ 그림1] 과 같이 횡축은 디자인 축으로 우측은 현대적 좌측은 고전적, 종축은 가격으로 위는 비싼 것이고 아래는 싼 것으로 공간을 정하였고, 각각의 위치는 $>$ 으로 표시하였다. 소비자들(30명) 의 이상점도 [그림2] 의 '+' 와 같이 정하였다. 이를 바탕으로 가상의 선택자료를 만들어서 [ 그림1] 의 상표위치와 함께 모 델에 적용하여 보았더니 [ 그림2] 의 뫄 같이 세분시장이 구분되어 세분시장 이상점을 찾아 내었다. 세 개의 세분시장은 각각 좋아하는 디자인의 정도와 가격의 정도가 다른 것을 알 수 있다.

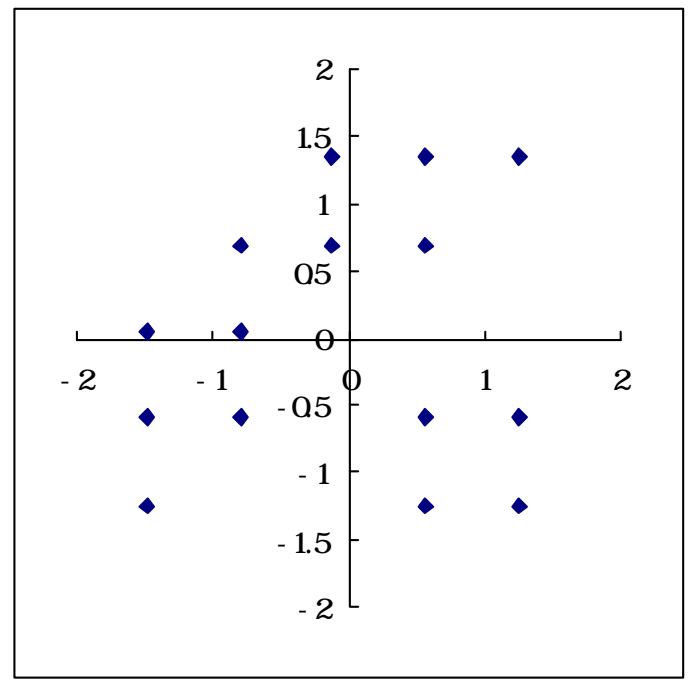

1999. 9

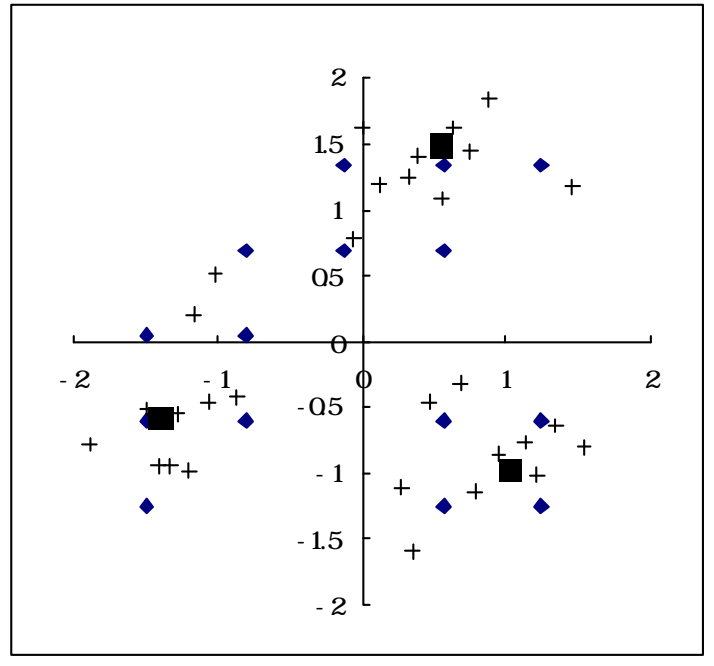

세그멘트변화를 추적하는 다차원척도법 
[ 그림2] 를 보면, 세분시장의 위치와 개수가 실제 소비자들의 이상점의 군집을 제대로 대표 하고 있는 것을 볼 수 있다. 실제로 정확한 세분시장의 수를 몰랐을 경우를 가상하여, 세 분시장을 2 개 혹은 4 개로 정하고 모델을 적용한 결과 아래 [ 표1]에서 보는 것과 같이 참된 개수를 CAl 아 BI C와 같은 통계치로 판별해 낼 수가 있었다. 참된 세분시장 개수를 찾는 방 법은 $\mathrm{CAlC}, \mathrm{BC}, \mathrm{AC}$ 의 값이 가장 적은 세분시장 개수를 선택하는 것이다. 최적 세분시장을 결정하고 모델의 적합도를 측정하는 통계치로 phi coefficient, total matching coefficient, summed absol ute difference를 사용하였다 (김주영 1999; Jedi di and DeSarbo 1991). 이러 한 통계치 들은 모델의 선택자료 예측치와 실체치간의 관계를 보여주는 통계치들로서 $\mathrm{SAD}$ 는 아래 [ 표2] 에 나온 예측치와 실체치간의 차이를 실체치로 나눈 비율을 평균한 값이다. $\mathrm{PH}$ 나 $\mathrm{TMC}$ 는 1 에 가까울수록 좋은 모델임을 나타내고, $\mathrm{SAD}$ 는 $\mathrm{O}$ 에 가까울수록 좋은 모델임을 나 타낸다. 불행하게도 각 통계치에 대한 분포가 연구된 것이 없어서 경험치 밖에는 제공할 수 없지만, 연구자 개인적인 생각으로는 $\mathrm{PH}$ 나 $\mathrm{TMC}$ 는 0.70싱, $\mathrm{SAD}$ 는 0.150|하면 적당하다고 생각된다.

\begin{tabular}{|c|c|c|c|c|c|c|c|}
\hline 세분시장수 & $-\mathrm{LN}$ & $\mathrm{PH}$ & $\mathrm{TMC}$ & $\mathrm{SAD}$ & $\mathrm{CAl}$ C & $\mathrm{Bl} \mathrm{C}$ & $\mathrm{Al}$ C \\
\hline 2 & 421.6 & .543 & .758 & .410 & 992.9 & 958.9 & 911.2 \\
\hline 3 & 210.5 & .874 & .944 & .084 & 711.5 & 645.5 & 553.0 \\
\hline 4 & 192.9 & .923 & .967 & .078 & 817.2 & 719.2 & 581.8 \\
\hline
\end{tabular}

[표 1: 현재위치에서 다른 세분시장 개수 적용모델 결과]

모델의 다른 결과로 [표2]에는 각 제품별로 예측치와 실체치간의 차이를 보여주고 있으며, 실제 적용결과 차이가 음수로 크게나 면, 그 제품은 소비자가 선택할 가능성이 많은 데에도 불구하고 인지도나 cover age등에 문제가 있어서 기회를 살리지 못한 것이라고 할 수 있으며, 차이가 양수로 크게 나면, 상표력 등이 있다고 할 수 있다. [표2]는 가상의 자료를 사용하 였기 때문에 차이가 별로 나지 않고 있다.

\begin{tabular}{|c|c|c|c|c|c|c|c|c|c|}
\hline 상표 & $\begin{array}{c}\text { 점유율예 } \\
\text { 측 }\end{array}$ & $\begin{array}{c}\text { 판매 } \\
\text { 예측 }\end{array}$ & $\begin{array}{c}\text { 실제 } \\
\text { 판매 }\end{array}$ & 차이 & 상표 & $\begin{array}{c}\text { 점유율예 } \\
\text { 측 }\end{array}$ & $\begin{array}{c}\text { 판매 } \\
\text { 예측 }\end{array}$ & $\begin{array}{c}\text { 실제 } \\
\text { 판매 }\end{array}$ & 차이 \\
\hline 1 & 0.056 & 19.6 & 22 & -2.4 & 9 & 0.069 & 24.1 & 23 & 1.1 \\
\hline 2 & 0.088 & 31.1 & 29 & 2.1 & 10 & 0.061 & 21.6 & 21 & .6 \\
\hline 3 & 0.061 & 21.6 & 19 & 2.6 & 11 & 0.104 & 36.7 & 33 & 3.7 \\
\hline 4 & 0.065 & 23.0 & 23 & -0.04 & 12 & 0.077 & 27.2 & 28 & -0.8 \\
\hline 5 & 0.046 & 16.3 & 17 & -0.72 & 13 & 0.063 & 22.2 & 25 & -2.8 \\
\hline 6 & 0.023 & 7.9 & 10 & -2.1 & 14 & 0.087 & 30.7 & 27 & 3.7 \\
\hline 7 & 0.074 & 26.2 & 28 & -1.8 & 15 & 0.082 & 29.0 & 30 & -1.0 \\
\hline 8 & 0.042 & 14.7 & 17 & -2.3 & \multicolumn{1}{|c|}{} \\
\hline
\end{tabular}


[표 $2:$ 모델의 판매 예측자료]

\section{2.2 세분시장의 변화}

현재상태 $(t=1)$ 에서 시간이 흘러서 시장이 변화되면 모델이 시장이 변화되는 것을 제대로 파 악하는 가를 검증하는 첫 번째로 세분시장의 수가 변화하는 것을 가상으로 만들고 이를 검 증하였다.

(1) 세분시장의 증가 $(\mathrm{t}=2)$

소비자들의 이상점들이 [그림3] 과 같이 과거에는 3개의 군집에서 4개의 군집이 되도록 변했 고, 상표들의 위치는 동일하다고 가정하고 가상의 선택자료를 만들어서 모델에 적용해 보았 더니, [그림3] 과 같이 4개의 군집을 대표할 수 있는 4개의 세분시장이 찾아졌다. 실제상황 에서는 연구자가 세분시장이 4개로 변했는지 알 수 없으므로 세분시장이 3 개, 4 개, 5개인 경 우를 모두 모델을 적용해본 결과 [표3] 과 같이 모델은 4개의 세분시장모델이 최적이라는 것 을 밝혀내고 있다.

\begin{tabular}{|c|c|c|c|c|c|c|c|}
\hline 세분시장수 & $-\mathrm{LN}$ & $\mathrm{PH}$ & $\mathrm{TMC}$ & $\mathrm{SAD}$ & $\mathrm{CAl}$ C & $\mathrm{Bl}$ C & Al C \\
\hline 3 & 277.1 & .774 & .896 & .217 & 844.6 & 778.6 & 686.1 \\
\hline 4 & 178.2 & .934 & .971 & .086 & 787.7 & 689.7 & 552.4 \\
\hline 5 & 177.4 & .934 & .971 & .087 & 926.9 & 796.9 & 614.7 \\
\hline
\end{tabular}

[표 $3:$ 세분시장 증가시 다른 세분시장 개수 적용모델 결과]

또한 세분시장이 변경되면서, 기존의 3 개의 세분시장에 있던 소비자들이 4 개의 세분시장으 로 어떻게 변경되었는지를 보여주는 변환매트릭스가 [표 4] 에 나타나고 있다. 가상의 선택 자료를 만들 때 과거의 소비자들의 이상점 위치를 거의 무작위하게 새로운 4 개의 세분시장 으로 옮겼기 때문에, 어떤 체계가 있어보이지는 않지만, [표 4]에는 변환 결합확률 값이 나 타나 있다.

\begin{tabular}{|c|c|c|c|c|}
\hline & 우측상단 & 좌측상단 & 우측하단 & 좌측하단 \\
\hline 좌측하단 & .00 & .13 & .00 & .20 \\
\hline 우측상단 & .23 & .10 & .00 & .00 \\
\hline 우측하단 & .03 & .03 & .20 & .07 \\
\hline
\end{tabular}

[표 $4:$ 세분시장 증가시 세분시장간 변환확률] 

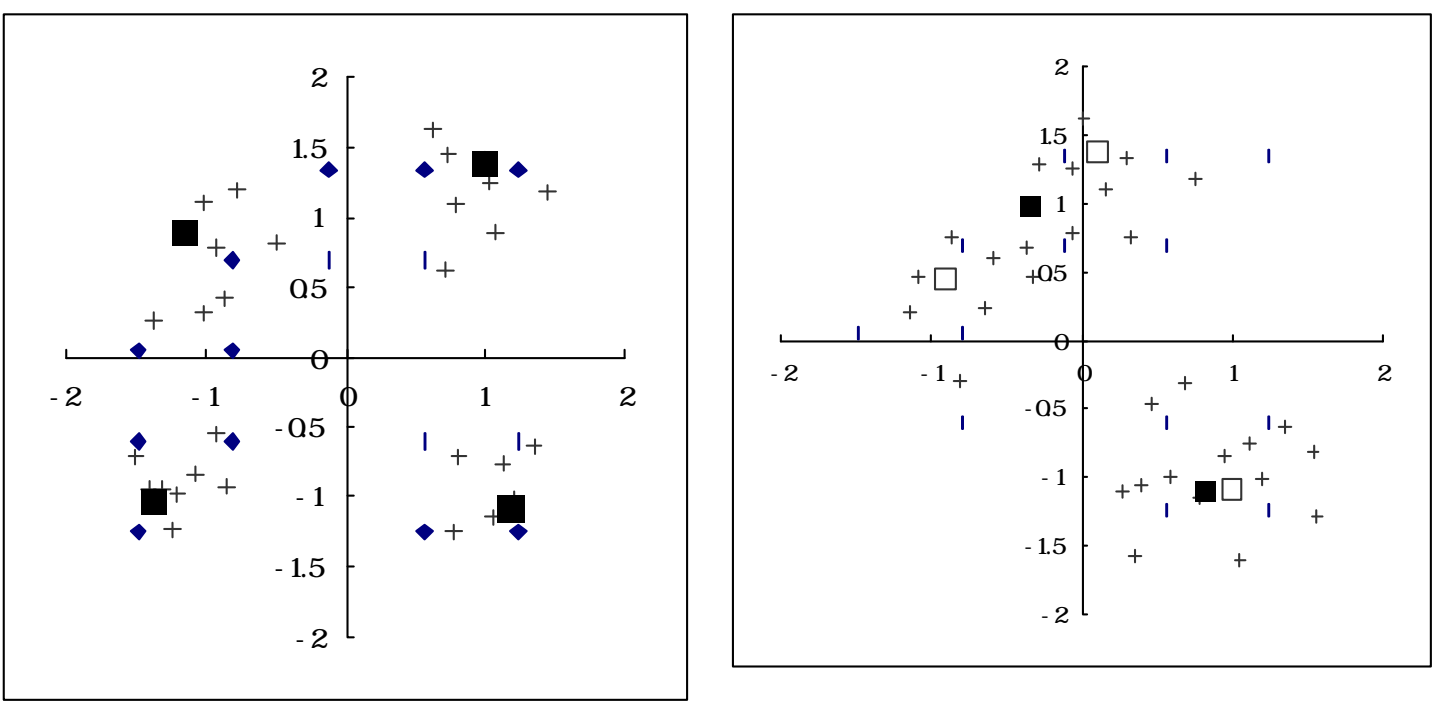

[그림 $3:$ 세분시장 증가의 경우]

[ 그림 $4:$ 세분시장 감소의 경우]

(2) 세분시장의 감소 및 제품수의 감소 $(\mathrm{t}=2)$

세분시장 감소의 경우도, 과거에는 3 개의 군집 ([그림2] 참조) 에서 시점 ( $\mathrm{T}=2$ ) 인 경우에는 [그림4] 와 같이 2개의 군집으로 변하고, 또 상표의 수도 2개가 감소한 경우라고 가정하고, 선택자료를 만들어서 모델을 적용해본 결과 [ 그림4] 와 같이 세분시장의 위치가 찾아졌다. 마찬가지로 [ 표5] 에서 세분시장의 최적수를 찾기 위해 여러 가지 세분시장개수를 적용해본 결과 최적세분시장 개수는 2 개라는 것을 확인할 수 있었다. 그러나 세분시장개수가 3 인 경 우가 BIC와 PH, TMC, SAD등이 좋았던 것으로 보아서 사실 2개인 경우와 3개인 경우가 명확 하게 결정을 내리기가 쉽지 않다. 실제로 [그림4]를 보면 실제 이상점 ' +' 들의 군집이 2개 인지 3개인지가 뚜렷하지 않아서, 이러한 특성이 모델결과의 통계적 특성에 반영되었다고 할 수 있다. 참고로 세분시장개수가 3개인 모델결과의 세분시장위치는 [그림4]에 ' $\square$ '으로 표시되어 있다.

\begin{tabular}{|c|c|c|c|c|c|c|c|}
\hline 세분시장수 & $-\mathrm{LN}$ & $\mathrm{PH}$ & $\mathrm{TMC}$ & $\mathrm{SAD}$ & $\mathrm{CAl} C$ & $\mathrm{BI} C$ & $\mathrm{Al} C$ \\
\hline 1 & 545.2 & .120 & .510 & .626 & 1099.1 & 1097.1 & 1094.3 \\
\hline 2 & 254.5 & .741 & .874 & .191 & 658.6 & 624.6 & 576.9 \\
\hline 3 & 192.3 & .887 & .946 & .083 & 675.1 & 609.1 & 516.7 \\
\hline 4 & 191.8 & .887 & .946 & .088 & 814.9 & 716.9 & 579.6 \\
\hline
\end{tabular}

[표 $5:$ 세분시장 감소시 다른 세분시장 개수 적용모델 결과] 


\subsection{3 차원수의 변화}

(1) 차원수의 증가 $(\mathrm{t}=2)$

차원수가 변화될 때 모델이 변화를 정확하게 알아내는가를 검증하기 위해서 과거 $(t=1)$ 일인 경우에는 2개 차원만 있다가 시간이 흐르면서 [ 그림5-1, 5-2] 와 같이 차원이 3개로 증가하 는 상황을 만들어서 선택자료를 만든 후에 모델에 적용하여 보았다.

이때 새로 생긴 차원을 보면, 과거 [ 그림1] 의 1사분면( 우측상단) 에 있던 소비자군집이 새로 생긴 차원 ([ 그림 5 2] 의 종축)에서 양의 값을 가지고 나머지는 0이나 음의 값을 갖게 하여, 주로 1사분면에 있던 소비자군집이 새로 생긴 차원(혹은 소비자들이 고려하기 시작한 제품 의 특징, 앞의 예에서는 입 냄새제거제의 미백효과)에 민감하다고 가정하였다. 또한 상표 2개를 새로 추가 시켰으며 ('O'으로 표시), 새로 추가된 상표들과 기존 상표들을 모두 새로 생긴 차원에 따라서 재 평가한 값이 [그림 5-2]의 종축에 나타나있다.

제품의 특징은 [표6]에 나타난 바와 같이 차원이 3개인 경우가 가장 결과가 좋았기 때문에 모델이 제대로 차원의 변화를 알아낸다고 할 수 있다. [그림 5-1, 5-2] 에는 세분시장의 위 치추정치가 나타나 있다.

\begin{tabular}{|c|c|c|c|c|c|c|c|}
\hline 차원 & $-\mathrm{LN}$ & $\mathrm{PH}$ & $\mathrm{TMC}$ & $\mathrm{SAD}$ & $\mathrm{CAl} C$ & $\mathrm{BI} C$ & $\mathrm{Al} \mathrm{C}$ \\
\hline 2 & 269.4 & .694 & .875 & 1.672 & 829.3 & 763.3 & 670.8 \\
\hline 3 & 214.6 & .783 & .918 & .165 & 732.9 & 663.9 & 567.2 \\
\hline 4 & 214.4 & .818 & .924 & .106 & 745.8 & 673.8 & 572.9 \\
\hline
\end{tabular}

[표 $6:$ 차원수 증가시 다른 차원 개수 적용모델 결과]

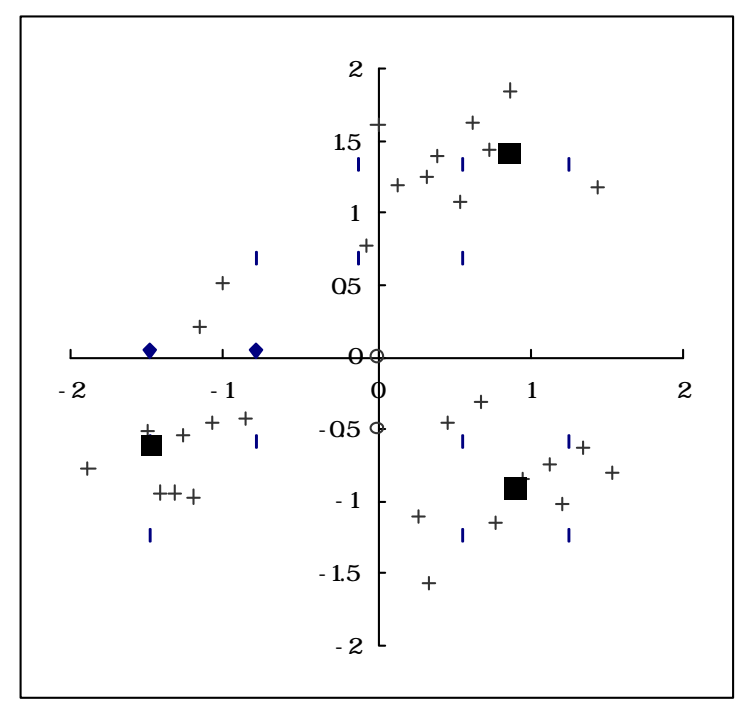

1999. 9

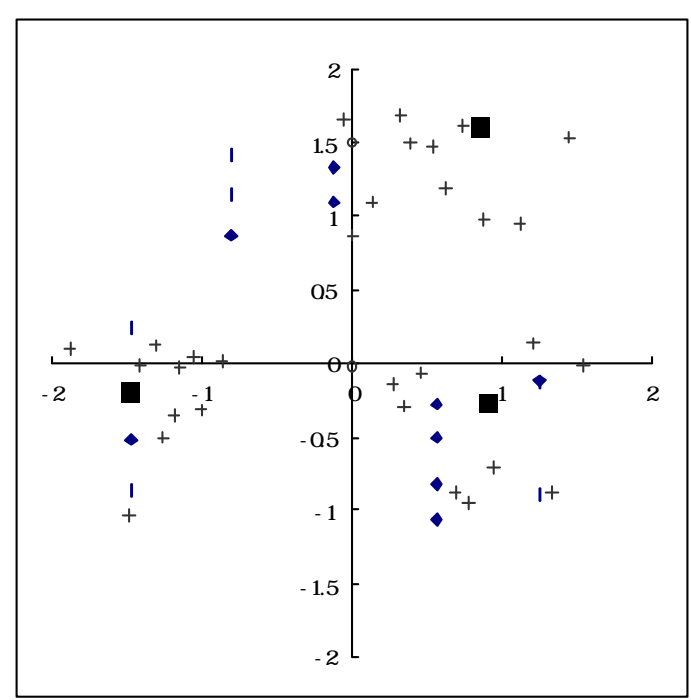

세그멘트변화를 추적하는 다차원척도법 17 
(2) 차원수의 감소 $(\mathrm{t}=3)$

마찬가지로 차원이 감소가 된 경우를 알아보기 위해서, $\mathrm{t}=2$ 에서 시간이 더 경과해서 $\mathrm{t}=3$ 이 되었을 때, 차원이 3 차원에서 2 차원으로 감소된 경우를 가정하여 보았다. 차원이 감소된 경우의 상황과 그때의 추정치는 [ 그림 6]에 나타나 있다. [표 7]은 서로 다른 차원을 가정 했을 때의 모델평가치를 보여주며, 역시 모델은 차원의 변화를 올바르게 찾아내고 있었다. 하지만 3 차원모델의 경우 일반적으로 2 차원모델보다 - likeli hood 함수의 값이 더 작은 것이 일반적이지만, 본 모델의 경우는 추가된 3차원에 대한 제품의 정보가 도움이 되기 보다는 제약조건으로 작용하여 Ii kel i hood 함수의 값이 오히려 2차원 결과보다 나쁘게 나왔다.

\begin{tabular}{|c|c|c|c|c|c|c|c|}
\hline 차원 & $-\mathrm{LN}$ & $\mathrm{PH}$ & $\mathrm{TMC}$ & $\mathrm{SAD}$ & $\mathrm{CAl} C$ & $\mathrm{Bl} \mathrm{C}$ & $\mathrm{Al}$ C \\
\hline 2 & 210.5 & .874 & .944 & .085 & 711.6 & 645.5 & 553.1 \\
\hline 3 & 218.2 & .897 & .956 & .175 & 740.2 & 671.2 & 574.5 \\
\hline
\end{tabular}

[표 7 : 차원수 감소시 다른 차원 개수 적용모델 결과]

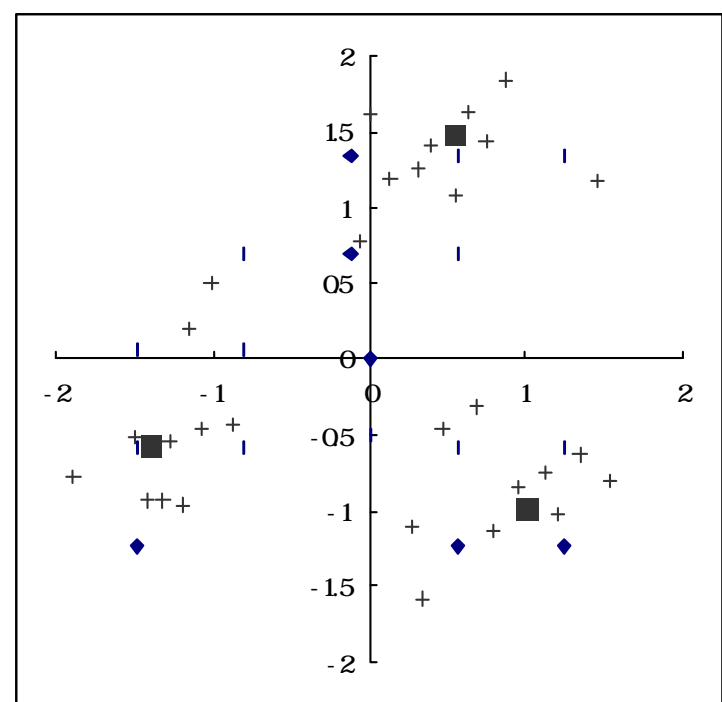

[그림 6 : 차원감소의 경우]

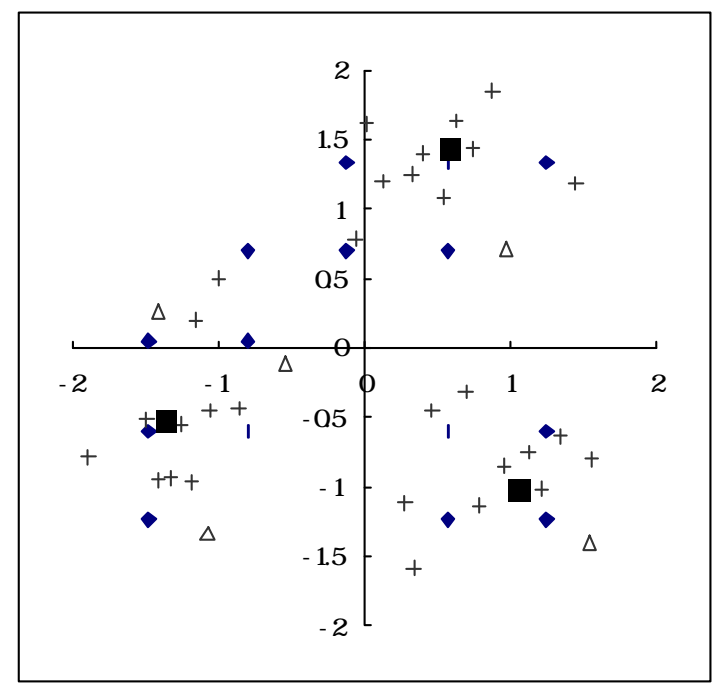

[그림 $7:$ 사람증가의 경우]

\subsection{4 응답자의 증가 $(\mathrm{t}=2)$}

응답자들이 변동되는 것을 모델이 제대로 반영하는 가를 평가하기 위해서 새로운 소비자를 5 명 추가하여 검증하여 보았다. [그림 7] 에 새로운 소비자들의 위치를 추가하였으며 ( $\triangle$ 로 표시), 모델은 새로운 소비자를 포함해서 안정적으로 세분시장의 위치를 보여주고 있다. 
이들 소비자들을 포함해서 각 세분시장에서의 소비자수와 시장크기는 아래 [표 8] 과 같다. 마찬가지로, 세분시장이 변했을지도 모르기 때문에 서로 다른 세분시장개수를 이용한 모델 결과는 [표 9]에 보여지며, 모델은 올바른 세분시장개수를 보여주고 있다.

\begin{tabular}{|c|c|c|}
\hline 세분시장 & 소비자수 & 시장크기 \\
\hline 좌측하단 & 13 & 147 \\
\hline 우측하단 & 11 & 128 \\
\hline 우측상단 & 11 & 131 \\
\hline
\end{tabular}

[표 8 : 응답자 증가시 세부시장의 크기]

\begin{tabular}{|c|c|c|c|c|c|c|c|}
\hline 차원 & $-\mathrm{LN}$ & $\mathrm{PH}$ & $\mathrm{TMC}$ & $\mathrm{SAD}$ & $\mathrm{CAl} C$ & $\mathrm{Bl} C$ & $\mathrm{Al} C$ \\
\hline 2 & 482.3 & .553 & .764 & .406 & 1142.2 & 1103.2 & 1042.5 \\
\hline 3 & 250.6 & .866 & .941 & .086 & 847.3 & 771.3 & 653.1 \\
\hline 4 & 238.9 & .877 & .945 & .073 & 992.7 & 879.7 & 703.9 \\
\hline
\end{tabular}

[표 $9:$ 응답자증가시 다른 세분시장 개수 적용모델 결과]

\section{5. 토의}

지금까지 소비자의 pi ck any/N자료와 상표의 특성을 통한 위치자료를 이용해서 세분시장을 나누고, 각 세분시장의 이상점을 구하고, 각 이상점들이 시간이 흐름에 따라서 어떻게 변화 되는지를 찾아내는 새로운 external 다차원척도 모형을 제시하였다. 새로운 다차원 척도모 형은 학문적이나 실무적으로 다음과 같은 기여가 있다고 생각된다.

첫째로 시간이 경과함에 따라서 변화되는 것을 실증적으로 파악할 수 있게 되었다. 물론 시간이 경과함에 따라서 세분시장이 어떻게 변화하는지에 대한 이론적인 설명이 가능하고 이것에 대한 이론을 찾을 수 있으면, 보다 완벽한 모델을 구축할 수 있겠다. 하지만 시간 의 흐름에 따라 세분시장이 어떻게 변화하는 가는 제품이 어떻게 변화하고, 소비자의 특성 들이 어떠한 지를 알아야 가능한 일인데 아직까지 이러한 이론은 발달되지 않았으며, 어쩌 면 가능하지 않은 일일수도 있다. Grover와 Srini vasan (1989)는 마케팅변수에 따라서 시 장점유율의 변동을 모델화한 경우는 있다. 따라서 동적인 변화를 찾아내는데 본 모델과 같 은 경험적인 모형의 개발은 매우 가치 있다고 생각된다. 현재의 모형은 동적인 변화를 매 시점마다 단속적으로 추정하고 있으나 이들간에 변화를 연속함수로 개발하는 것이 추후의 연구과제라고 할 수 있다 (cf. Grover and Sri ni vasan 1989).

둘째로 external 모형을 개발하여 기존의 많은 internal 모형이 가지고 있었던 문제점들, 차 원의 축소, 차원의미의 확인, 차원변동의 불변성과 같은 문제점들을 해결하였다. 이것은 external 모형이 가지는 일반적인 장점이기는 하지만 본 모형은 시간변동을 포함한 모형이 가져야 하는 필수적인 특성들에 external 모형의 장점을 잘 적용시켰다는데 의의가 있다고 하겠다. 또한 선택모형에서 많이 사용하는 제품의 특성을 이용하면, external 모형의 한계 
한 국 마 케 팅 저 널 제 1 권 제 4 호

점을 완화해주는 방법도 제시했다고 할 수 있다. 본 모델을 처음 구축하면서 internal 모델 도 만들어서 실제로 운영해본 결과 기존에 internal 모델이 가지는 많은 문제점들이 발견되 었고, 이들이 시간의 변동에서 요구되는 조건들과 합쳐져서 안정적인 결과를 가져오지 못했 다.

세 번째는 세분시장 수준의 모델을 제시하여서 실험이나 서베이를 통한 자료가 아닌 실제 선택자료의 경우에 발생하는 자료의 불완전성을 완화해주었다. 많은 선택모형은 개인 모수 에 근거한 경우가 많은데, 개인수준의 모델의 경우는 표본이 이탈하거나 불응답인 경우 적 용하기가 힘들다. 특히 동적인 자료인 경우에는 이와 같이 자료가 불완전한 경우가 많은데, 본 모델은 동질적이라고 생각되는 경우에는 표본의 변동이 있어도 큰 무리 없이 적용할 수 가 있다.

네 번째는 실무적으로 사용하기에 무리가 없을 정도의 모델 안정성이다. 본 모델은 모델의 구조가 상대적으로 간단하고, 여러 가지 모델초기치 option을 만들어서 기존의 다차원척도 법들에서 보여지는 Iocal 최적치 문제를 완화해주고 있다. 따라서 실제자료를 이용해서 적 용하는데 편리하게 되어있다. 또한 실무적으로 처음 논문의 목적에서 밝힌 바와 같이 손쉽 게 포지셔닝맵을 그리는 목적을 달성했다고 하겠다. 하지만 본 모델은 실제 자료를 이용해 서 검증하지 못했기 때문에 추후에 여러 가지 산업의 자료를 이용해서 모델 전체적인 타당 성을 검증하는 것이 필요하다. 또한 보다 많은 모수를 추정할 수 있는 gi bbs sampl ing과 같은 최근의 기법들을 이용한다면 internal 한 모델도 추후에는 구축해 볼 수 도 있을 것이 다.

\section{참고문헌}

김근배와 이훈영 (1995), "기준축의 회전을 고정시킨 MDS: 포지셔닝맵의 합성에 응용, " 마케 팅연구, 제10권, 제 1호, pp.1-17

김주영 (1999), "Markov-선호변환을 이용한 동적 logit 모형, " 마케팅연구, 제14권, 제2호, pp. 1- 22

Carrol I, J. Dougl as and Phi pps Arabi e (1980), "Mul ti di mensi onal Scal i ng, " The Annual Revi ew of Psychol ogy, vol 31, pp. 607-649

C i ff, Norman (1969), "Orthogonal Rot at i on to Congr uence, " Psychometrika, 31, pp. 33- 42 Coopers, Lee G and Nasao Nakani shi (1983), "Two Logit Nodel s for External Anal ysi s of Pref er ences, " Psychomet ri ka, vol 48, no 4, pp. 607-620

Cooper, L. G. (1988), "Competitive Maps: The Structure underlying Asymmetric Cross El asti ci ti es, " Nanagement Sci ence, 34, 6, pp. 707- 723

Davi son, Mark L. (1983), Mul ti di mensi onal scal ing, New York : Wil ey

DeSar bo, W S. and V. R. Rao (1984), "GENFOLD2: A set of nodel s and al gorithms for the GENer al unFOLD ng Anal ysi s of Pref er ence/Doninnance Dat a, "J Jour nal of $\mathrm{d}$ assification, 1999. 9 세그멘트변화를 추적하는 다차원척도법 20 
vol 1 , pp. 147- 186

...... and J. Cho (1989), "A St ochasti c Mul ti di mensi onal Scal ing Vect or model for the Spatial representati on of bi nary choi ce data, " Psychonetrika, vol 54, pp. 105-129 ....... , Marti n Young R., and Arvi nd Rangaswany (1997), "A Par anetric Mul ti di mensi onal Unfol ding Procedure for Incompl ete Nonmetric Preference/Choi ce Set Data in Narketing Research," Journal of marketing research, vol 34, no 4, pp. 499516

El rod, Terry (1988), "Choi ce Nap : I nferring a Product- Narket Nap from Panel Dat a, " Narket i ng Sci ence, 7, pp. 21- 40

Green, Paul E. (1972), Appl i ed nul ti di mensi onal scal i ng; a compar i son of approaches and al gori thns, New York, Hol t, Ri nehart and Winst on

......, Ar un Naheshwari, and Vithal a R. Rao (1969), "Di mensi onal I nterpret at i on and Conf i gur ation I nvariance in Multidimensi onal Scaling: An Empirical Study, " Mul ti vari at e Behavi or al Research, 1, pp. 159- 180

.....- and Yor am Wnd (1973), Mul ti attri bute Deci si ons in Market ing: A measurement Approach, The Dryden Press

Grover, Raj i v and V. Sri ni vasan (1987), "A Si mul t aneous Approach to Narket Segment at i on and Narket Structuring," Journal of Narketing Research, 24, pp. 139153

..... and-... ( 1989), "An Approach for Tracking Wthi n Segnent Shi fts in Market Shares," Journal of Narketing Research, 26, pp. 230236

Jedi di, Kamel and Wayne S. DeSarbo (1991), "A St ochast i c Mul ti di mensi onal Scal ing Procedure for the Spati al Representation of Three Node, Thr ee- Way Pick Any/J Data," Psychometrika, vol 56, no 3, pp. 471- 494

Mi npour, Reza, Janes M McCul l ough, and Dougl as L. MacLachl an (1976), "Ti me Changes in Percepti on: A Longi tudi nal Appl i cati on of Mul ti di mensi onal Scal ing, " Journal of Narketing Research, 13, pp. 245-253

Peay, Edmund R. (1988), "Mul ti di mensi onal Rot at $i$ on and Scal ing of Conf $i$ gur at $i$ ons to Opt i mal Agr eement, " Psychomet ri ka, 53, pp. 199- 208

Ransay, J. O. ( 1977), "Naxi mum Li kel i hood Est i mati on in Mul ti di mensi onal Scal i ng," Psychometrika, vol 42, no 2, pp. 241- 266

..... (1980), "The Joi nt Anal ysis of Di rect Ratings, Pai rwi se Preferences, and Di ssimilariti es, " Psychometri ka, vol 45, no 2, pp. 149- 165

Si nha, I ndr aj it and Wayne S. DeSar bo, (1998), "An I nt egr at ed Approach Toward the Spat i al Model ing of Percei ved Cust oner Val ue, " Journal of marketing research, vol 35, no 2, pp. $236-249$

Tver sky, Anos and S. Sat tath (1979), "Pref er ence Trees, " Psychol ogi cal Revi ew, 86, pp. $542-573$

Ranaswany, Venkatr am and Wayne S. DeSar bo ( 1990), "SquPTRE: a new nethodol ogy for der i vi ng and anal yzi ng hi er archical product - market st ructures frompanel data, " Jour nal of Narketing Research, vol 27, no 4, pp. 418-428

Wedel, M chel and Wayne S. DeSarbo, (1996), "An Exponent i al - Fami l y Mul ti di mensi onal 1999. 9 세그멘트변화를 추적하는 다차원척도법 21 
Scal ing Mxture Nethodol ogy, " Journal of busi ness \& economic statistics, vol 14, no 4, pp. 447- 459

Young, For rest W (1987), Mul ti di mensi onal scal ing : hi st ory, theory, and appl i cati ons, H I I sdal e, N. J. : L. Erl baum Associ at es

\section{Appendi $\mathrm{x}$}

\section{A. 1 모델 결과}

적합도 측정치 : I i kel i hood 함수값, Al C, CAl C, Bl C

hit-ratios : PH, TMC, SAD

세분시장 귀속확률 : $\mathrm{E}$ 단계에서 구해지는 모수추정치, $\mathrm{S}_{\mathrm{ist}}$ 세분시장 이동 : $M$ 단계에서의 모수추정치, $\mathrm{a}_{\mathrm{sk}}$ 모수추정오차 : $\mathrm{M}$ 단계에서 구해지는 모수들에 대한 standard error 세분시장의 위치 : 과거 세분시장의 위치와 세분시장 이동을 더한 위치, $\mathrm{Y}_{\mathrm{sk}}+\mathrm{a}_{\mathrm{sk}}$ 세분시장 귀속전환 행렬 : 과거 귀속된 세분시장에서 새로운 세분시장으로 조건부 전환행렬 [ $\mathrm{t}-1$ 기의 세부시장수 $\mathrm{x}$ t기의 세분시장수] 세분시장의 크기 : 각 세분시장 귀속확률과 소비자들의 선택을 고려한 추정치 시장점유율 : 소비자들의 선택확률 예측치와 과거 총 선택수에 근거한 추정치 실제선택과 예상선택과의 차이 : 모델의 예측선택과 실제선택과의 차이를 상품별로 나타내 주는 것으로 상품의 전략수립에 도움이 되는 분석자료

\section{A. 2 모델 적용단계}

참고로 본 프로그램과 운영요령은 저자의 home page [http: //kmu. kookmn. ac. kr/ j ki npㅔㅅㅓ down 받아서 실제로 적용해 볼 수 있다.

(1) 모델을 처음 적용하는 경우

(1) 외부 입력자료를 구한다

( 소비자선택자료와 상품의 위치)

(2) 내부 모델옵션들을 정한다

(세분시장의 수, 세분시장 귀속확률 초기치 옵션, 세분시장 이동 초기치 옵션)

(3) 모델을 적용하여 결과들을 구한다

(세분시장의 위치, 세분시장 귀속확률, 적합도, 유의도, 판매예측등)

(2) 과거 모델을 적용한 결과가 있는 경우 
과거 모델을 적용한 결과가 있는 경우란, 동일한 혹은 비슷한 소비자들을 대상으로 얻은 자 료를 이용하여 본 모델로 분석을 한 적이 있는데, 이번에 다시 자료를 수집하여 분석을 하 고자 하는 경우를 말한다. 최소한 과거 분석결과로 세분시장의 위치가 있어야 하며, 소비 자들은 반드시 동일인이 아니어도 된다.

(1) 이번기의 입력자료를 구한다

( 소비자선택자료, 상품위치, 과거 세분시장 위치, 과거 세분시장 귀속확률)

(2) 내부 모델옵션들을 정한다

(세분시장의 수, 세분시장 귀속확률 초기치 옵션, 세분시장 이동 초기치 옵션)

(3) 모델을 적용하여 결과들을 구한다

(세분시장의 위치, 세분시장의 이동, 세분시장 귀속확률, 세분시장 귀속전환행렬, 적합도, 유의도, 판매예측등) 